\title{
Flourishing of information technology professionals: Effects on individual and organisational outcomes
}

\author{
E. Diedericks and S. Rothmann* \\ Optentia Research Focus Area, North-West University, Vanderbijlpark \\ ian@ianrothmann.com
}

\begin{abstract}
The aim of this study was to investigate the relationship between flourishing and individual and organisational outcomes, including job satisfaction, organisational commitment, organisational citizenship behaviour, turnover intention and counterproductive behaviour. A convenience sample $(N=205)$ was taken of employees in information technology organisations in South Africa. A biographical questionnaire, the Mental Health Continuum Short Form, Job Satisfaction Scale, Organisational Commitment Scale, Turnover Intention Scale, Organisational Citizenship Behaviour Scale and a Counterproductive Behaviour Scale were administered. Flourishing affected job satisfaction, organisational commitment, organisational citizenship behaviour and organisational commitment directly and indirectly. Job satisfaction had strong direct effects on organisational commitment (positive) and turnover intention (negative), and a moderate negative effect on counterproductive work behaviour. Flourishing affected turnover intention indirectly and negatively via organisational commitment.
\end{abstract}

Keywords: Flourishing, job satisfaction, organisational commitment, turnover, organisational citizenship behaviour, counterproductive behaviour

*To whom all correspondence should be addressed.

\section{Introduction}

Organisations worldwide are challenged by the task of attracting and retaining talented employees (Bakker \& Schaufeli, 2008). In the light of the serious skills deficit and the prediction of a possible shortage of 29027 information technology (IT) professionals for South Africa in 2015, the attraction and retention of IT professionals is a big challenge. Not only is there a global shortage of qualified candidates (Lowry, Turner \& Fisher, 2006; Turner \& Lowry, 2000), but also a high turnover of IT professionals (Moore \& Burke, 2002; Roodt \& Paterson, 2008). Voluntary employee turnover caused by high levels of job dissatisfaction is extremely costly (Lambert, Hogan \& Barton, 2001), and can amount to $70 \%$ to $200 \%$ of an employee's annual salary (Price, 2001). Therefore, the shortage of qualified information technology staff and retention of talented employees are probably the biggest challenges facing information technology organisations (Gaylard, Sutherland \& Viedge, 2005).

The challenge of attracting and retaining quality IT professionals should be approached from a strategic human resource management perspective (Armstrong, 2006). High commitment-high involvement management is one specific approach aimed at eliciting and supporting behaviour that is primarily self-regulated rather than controlled by sanctions and pressures external to employees. In the high commitment-high involvement approach, constructs such as job satisfaction (Price, 2001), organisational commitment (Torrington, Hall \& Taylor, 2008), organisational citizenship behaviour (Robbins, Judge, Odendaal \& Roodt, 2009), turnover intention (Armstrong, 2006) and counterproductive behaviour (Spector \& Fox, 2005) are relevant. These constructs could be affected by the level of subjective well-being of employees (Bowling, Eschleman \& Wang, 2010; Sparks, Faragher \& Cooper, 2001), as employee and organisational well-being are both influenced by employees' personal strengths, but also by their interaction with their work environments (Bergh \& Theron, 2012). Therefore, a balanced managerial approach towards utilising employees' strengths, but also addressing personal adjustment problems and work dysfunctions is paramount in enhancing optimal well-being (Bergh \& Theron, 2012).

Diener, Kesebir and Lucas (2008) define subjective wellbeing in terms of the judgment an individual makes over his or her own life and its events in three domains, namely cognitive (life and domain-specific satisfaction), positive and negative affective experiences. In contrast, Keyes (2005) takes a broader view towards well-being and distinguishes between three dimensions of subjective wellbeing, namely emotional well-being (which indicates hedonic well-being or "feeling well"), psychological wellbeing and social well-being (which indicate eudaimonic well-being or "functioning well”). Lyubomirsky, King and Diener (2005) studied the benefits of frequent positive affect (i.e. the emotional dimension of flourishing) for success in multiple life domains. They found that the positive affectsuccess link existed not only because success leads to positive affect, but also because positive affect engenders success. Concerning the work context, cross-sectional 
studies reviewed by Lyubomirsky et al. (2005) showed that frequent positive affect is associated with performance and productivity, job satisfaction, organisational citizenship behaviour and less withdrawal behaviour (e.g., turnover intention).

Although Lyubomirsky et al. (2005) suggested that employees who are emotionally well showed adaptive characteristics (e.g., psychological and social well-being); this study takes a different perspective. Frequent positive affect (i.e. emotional well-being or "feeling well") is only one dimension of flourishing (Keyes, 2005). The other two dimensions are psychological and social well-being. Together, these three dimensions reflect the extent to which individuals are feeling and functioning well. Individuals who flourish will probably show better individual and organisational outcomes, not only because they feel well, but also because they function well (Keyes, 2002). Studies (Fredrickson, 2004; Keyes \& Haidt, 2003; Seligman \& Csikszentmihalyi, 2000; Tugade \& Fredrickson, 2004) have shown that positive feelings and positive functioning are to the benefit of both individuals and their employing organisations. Flourishing individuals are expected to show self-regulation, and higher levels of job satisfaction and commitment (Bowling et al., 2010; Harter, Schmidt \& Keyes, 2002). Languishing might result in low organisational commitment, counterproductive behaviour and unwanted employee turnover (Torrington et al., 2008). However, no studies were found which investigated the relationships between flourishing (as conceptualised by Keyes, 2007) and individual and organisational outcomes.

The aim of this study was to investigate the relationship between flourishing and individual and organisational outcomes such as job satisfaction, organisational commitment, organisational citizenship behaviour, turnover intention and counterproductive behaviour.

\section{Flourishing, individual and organisational outcomes}

According to Youssef and Luthans (2012), employees who flourish function within the optimal range and are characterised by growth and generativity. Flourishing encompasses individuals who thrive at work, as well as those who are happy, engaged, intrinsically motivated, successful and learning (Bono, Davies \& Rasch, 2012), and functioning well in life in general (Keyes, 2005). According to Keyes (2005), the presence of feeling well and functioning well results in flourishing of individuals, meaning that positive mental health is present. Keyes and Annas (2009) postulate that people's feelings and functioning in life are consistent because if they are functioning well, they experience positive emotions toward life; whereas if they are malfunctioning, they tend to experience negative emotions in life.

Keyes (2007) operationalised flourishing as a pattern of positive feelings and positive functioning in life, summarising the scales and dimensions of subjective well- being under the following sub-categories: emotional wellbeing, psychological well-being and social well-being (see Table 1). On the opposite continuum is languishing which can be defined as the absence of mental health. According to Keyes (2007), flourishing people are completely mentally healthy and function better than people with moderate mental health as well as those who are languishing. Flourishing is associated with good health, constructive coping, and positive organisational outcomes. Languishing is associated with health limitations and poor psychosocial functioning (Keyes, 2007; Keyes \& Annas, 2009).

\section{Table 1: Dimensions and factors reflecting mental health} as flourishing

\begin{tabular}{|c|c|}
\hline Dimension & Definition \\
\hline & $\begin{array}{l}\text { Emotional well-being } \\
\text { emotions/feelings) }\end{array}$ \\
\hline Positive affect & $\begin{array}{l}\text { Energetic, regularly cheerful, serene, } \\
\text { good-spirited }\end{array}$ \\
\hline Affirmed quality of life & $\begin{array}{l}\text { Showing general satisfaction and } \\
\text { happiness with life overall }\end{array}$ \\
\hline & $\begin{array}{ll}\text { Psychological well-being } & \text { (positive } \\
\text { psychological functioning) } & \end{array}$ \\
\hline Self-acceptance & $\begin{array}{l}\text { Positive attitudes toward self/own } \\
\text { personality }\end{array}$ \\
\hline Personal growth & $\begin{array}{l}\text { Ambitious, seeks to maximise own } \\
\text { potential }\end{array}$ \\
\hline Purpose in & Own life has direction and meaning \\
\hline Environmental mastery & $\begin{array}{l}\text { Shows ability to change and manage } \\
\text { personal environment to suit own needs }\end{array}$ \\
\hline Autonomy & $\begin{array}{l}\text { Has socially acceptable internal } \\
\text { standards and values as guidelines in life }\end{array}$ \\
\hline $\begin{array}{l}\text { Positive relations with } \\
\text { others }\end{array}$ & $\begin{array}{l}\text { Ability to establish trusting interpersonal } \\
\text { relationships }\end{array}$ \\
\hline & $\begin{array}{l}\text { Social well-being (positive social } \\
\text { functioning) }\end{array}$ \\
\hline Social acceptance & $\begin{array}{l}\text { Positive towards and accepting of } \\
\text { diversity in people }\end{array}$ \\
\hline Social actualisation & $\begin{array}{l}\text { Believes in potential of others } \\
\text { (individuals, groups and societies) }\end{array}$ \\
\hline Social coherence & $\begin{array}{l}\text { Finds society and social life meaningful } \\
\text { and comprehensible }\end{array}$ \\
\hline Social contribution & $\begin{array}{l}\text { Regards own daily activities as adding } \\
\text { value to society and others }\end{array}$ \\
\hline Social integration & $\begin{array}{l}\text { Experiences sense of relatedness, } \\
\text { comfort and support from community }\end{array}$ \\
\hline
\end{tabular}

Various theories could be used to understand the effects of flourishing on individual and organisational outcomes, namely the Broaden-and-Build (B\&B) theory (Fredrickson, 2001), spillover and expansionist theories (Hecht \& Boies, 2009) and part-whole theory (Bowling et al., 2010).

The B\&B theory (Fredrickson, 1998) postulates that people who experience positive emotions, will intensify their personal resources, which will lead to well-being (Ouwencel, LeBlanc \& Schaufeli, 2011). Flourishing individuals possess a wide scope of cognitive, physical and social possibilities, which together culminate in empirical 
and actual successes of a flourishing life (Fredrickson, 1998). Thus, an individual who feels well is more likely to function well, both psychologically and socially, which means meeting the criterion for positive mental health as flourishing.

According to spillover theory, positive and negative spillovers are expected to contribute both independently of each other as well as with contradictory consequences to the prediction of outcomes (Hecht \& Boies, 2009). Employees who flourish experience positive feeling and functioning which will spill over to their work (Hecht \& Boies, 2009). Consequently, flourishing employees will exhibit positive individual and organisational outcomes such as job satisfaction, organisational commitment, organisational citizenship behaviour, and less turnover intention and counterproductive behaviour (Bakker, Demerouti \& Schaufeli, 2003; Harter, Schmidt \& Hayes, 2002; Ouwencel et al., 2011). The expansionist theory suggests that participation in one specific role can increase the resources that individuals have for other roles.

Bowling et al. (2010) refer to the part-whole theory (job satisfaction is regarded as a sub-dimension of subjective well-being) to explain the causal relationship of job satisfaction with subjective well-being, whereas the dispositional approach states that subjective well-being has a causal relationship with job satisfaction. Individuals who are subjectively well, a requirement for mental health as flourishing, are said to exhibit more job satisfaction than those who are not.

Sverke, Hellgren and Näswall (2002) group psychological outcome variables according to proximal variables, which refer to outcomes that are affected directly, and distal variables which are affected indirectly because they develop over time or because they are mediated by proximal variables (De Cuyper \& De Witte, 2007). Distal outcome effects seem to be weaker compared to proximal factors. Variables can also be grouped as those that have direct consequences for the individual and indirect consequences for the organisation, and those that are primarily of organisational concern (De Cuyper \& De Witte, 2007).

\section{Proximal and individual: Job satisfaction}

Job satisfaction refers to employees' attitudes and feelings toward their work. Job satisfaction is indicative of positive and favourable attitudes toward the job, whereas negative and unfavourable attitudes toward the job indicate job dissatisfaction (Armstrong, 2006). An employee with positive affect and life satisfaction (which are criteria for the emotional component of flourishing) will exhibit more job satisfaction (Connolly \& Viswesvaran, 2000; Le Pine, Erez \& Johnson, 2002; Thoresen, Kaplan, Barsky, Warren \& de Chermont, 2003). Bowling et al. (2010) found positive relationships between job satisfaction and life satisfaction on the one hand, and positive affect and the absence of negative affect (both dimensions of emotional well-being) on the other. Personal resources can be linked to positive selfevaluations which relate to resilient behaviour, environmental mastery, and to achieving goals (which relates to having a purpose in life, i.e. psychological wellbeing); all of which strongly relate to job satisfaction (Judge, Van Vianen \& De Pater, 2004). In their longitudinal studies, it was suggested that there was a stronger causal relationship from subjective well-being to job satisfaction than from job satisfaction to subjective well-being (Bowling et al., 2010). Therefore, individuals who are emotionally, psychologically and socially well will experience more job satisfaction than individuals who are not subjectively well.

\section{Proximal and organisation: Organisational commitment}

Organisational commitment refers to attachment to the organisation, goal attainment, identifying with the organisation, loyalty and trustworthiness towards the organisation (Harrison \& Hubbard, 1998). According to Meyer and Allen (1997), employees who show strong affective commitment want to stay with the organisation as they are related to and identify with the organisation which enhances their involvement in organisational activities. Trimble (2006) found that job satisfaction predicted affective organisational commitment. Cohen (2003) states that the importance of organisational commitment as a research topic can be related to the fact that it provides a clearer understanding of the nature of the psychological process through which individuals master their environments and find purpose in life (psychological wellbeing).

\section{Distal and organisation: Turnover intention}

In a longitudinal study done on organisational commitment, job satisfaction and turnover amongst psychiatric technicians, it was reported that organisational commitment discriminated better between stayers and leavers than did the various components of job-satisfaction (Porter, Steers, Mowday \& Boulian, 1974). Trimble (2006) showed that low affective organisational commitment leads to turnover intention. Research shows that an individual's level of organisational commitment is a better predictor of turnover than job satisfaction, explaining $34 \%$ of the variance (Robbins et al., 2009). According to Thatcher, Stepina and Boyle (2002), organisational commitment is the primary indicator of turnover intention. Rhoades, Eisenberger and Armeli (2001) found that positive work conditions increase affective commitment which in turn leads to low employee turnover.

\section{Distal and organisation: Organisational citizenship behaviour}

Organisational Citizenship Behaviour (OCB) is defined as employee behaviour that contributes more to an organisation than the job basically requires (Lambert, 2006). OCB comprises four dimensions: helping (altruism), loyalty, advocacy, functional participation and obedience. Helping is the extent to which the individual offers actions to others; loyalty refers to identifying with or loyalty to the organisation (defending the organisation, being co-operative and serving the interests of the organisation); advocacy is behaviour aimed at others within the organisation, maintaining high standards, challenging others, suggesting change; whilst functional participation has a more personal focus, although still contributing towards organisational 
effectiveness (Coyle-Shapiro, 2002; Van Dyne, Graham \& Dienesch, 1994).

Humanistic psychological theory proposes that a prosocial or altruistic orientation is the major motivator for all mankind. People find meaning through their unselfish, philanthropic acts towards others (Morgan \& Farsides, 2008). Already in earlier studies job satisfaction showed a direct predictive path to altruism (Smith, Organ \& Near, 1983). Altruism relates strongly to the dimension of positive social functioning of flourishing behaviour. Moore and Love (2005) state that information technology professionals show significantly lower OCB (e.g., assisting other employees learn a new software system, acting as informal mentors to new employees) than professionals in non-IT areas, which they attribute to perceptions of unfairness with regard to work overload.

Job satisfaction is a major determinant of OCB (Robbins et al., 2009). Manifestation of OCB arising from job satisfaction has its theoretical foundation in Blau's (1964) social exchange theory. Blau describes social exchange as an open-stream of resource transactions by developing and supporting employee relationships founded in trust (Rousseau, 1998). Robbins et al. (2009) state that satisfied employees would be more likely to talk positively about the organisation, assist others and generally do more than expected in the line of duty (social well-being). When employees perceive that they are empowered by the organisation, i.e. by receiving the necessary resources, they will put in extra effort or do more than what is expected from them within the work environment (Organ, 1988). Bateman and Organ (1983) in their study indicated that job satisfaction has a significant and positive relationship with OCB, ranging from 0,19 to 0,25 .

In a study of educators in Turkey, it was found that organisational citizenship behaviour is related to organisational commitment (Yilmaz \& Cokluk-Bokeoglu, 2008). Le Pine et al. (2002) indicate that whereas past researchers (such as Organ, 1988) proposed the relation between OCB and organisational commitment not beyond utilising factor analysis, they used meta-analysis to demonstrate the strong relation between OCB and organisational commitment. Based on the social exchange theory (Organ, 1988, 1990), employees exhibit citizenship behaviour to requite the treatment they received from the organisation. When this treatment is perceived as positive, employees are more inclined to perform citizenship behaviour, because they regard it as a role obligation towards the organisation rather than discretionary (CoyleShapiro \& Kessler, 2002). Positive citizenship behaviour (psychological and social well-being) leads to greater affective commitment (emotional well-being) towards the organisation in general which result in flourishing behaviour.

\section{Distal and organisation: Counterproductive behaviour}

Counterproductive behaviour refers to acts that harm organisations or their people (Spector \& Fox, 2005). Spector et al. (2006) distinguish between five types of counterproductive behaviour, namely abuse (harmful behaviours that affect other people); production-deviance (purposely doing one's job incorrectly or allowing errors to occur); sabotage (destroying organisational property); theft (wrongfully taking the personal goods or property of another); and withdrawal (avoiding work through being late or absent). Linked to the issue of ethical behaviour is the matter of internet abuse (that is the use of the internet for non-work-related purposes) which is regarded as a fundamental problem in organisations (Woon \& Pee, 2004). Internet abuse can have dire consequences such as bandwidth waste, legal liability, and exposing the organisation to threats. According to Chang and Cheung (2001), positive affect and more specifically an inclination towards pleasure are important predictors of internet usage intention. Job dissatisfaction and disengagement at work have been linked to internet abuse $(p<0,05)$, whilst social norms and perceived behavioural consequences also contribute significantly to internet abuse (Woon \& Pee, 2004). It can be inferred that flourishing individuals who exhibit greater job satisfaction which relates positively to OCB, which relates positively to organisational commitment, which relates positively to turnover intention, will exhibit less counterproductive behaviour at work.

\section{Hypotheses}

Based on a review of the literature, it is expected that information technology professionals' flourishing will have direct effects on their job satisfaction, which in turn affects their organisational commitment, OCB and counterproductive work behaviour. It is also expected that IT professionals' level of flourishing will indirectly affect job satisfaction, organisational commitment, OCB and counterproductive work behaviour.

The research question for this study is as follows: Does flourishing affect individual outcomes, namely job satisfaction; and organisational outcomes (organisational commitment, OCB and counterproductive work behaviour)? Given the analytical strategy and based on the literature review, the following hypotheses were set for this study:

$\mathrm{HO}_{1}$ : Flourishing does not relate positively to job satisfaction. / $\mathrm{H}_{1}$ : Flourishing relates positively to job satisfaction.

$\mathrm{HO}_{2}$ : Job satisfaction does not relate positively to organisational commitment. / $\mathrm{H}_{2}$ : Job satisfaction relates positively to organisational commitment.

$\mathrm{HO}_{3}$ : Flourishing does not relate positively to organisational commitment. / $\mathrm{H}_{3}$ : Flourishing relates positively to organisational commitment.

$\mathrm{HO}_{4}$ : Organisational commitment does not relate negatively to turnover intention. / $\mathrm{H}_{4}$ : Organisational commitment relates negatively to turnover intention. 
$\mathrm{HO}_{5}$ : Job satisfaction does not indirectly affect turnover intention via organisational commitment. / $\mathrm{H}_{5}$ : Job satisfaction indirectly affects turnover intention via organisational commitment.

$\mathrm{HO}_{6}$ : Job satisfaction does not relate positively to OCB. I $H_{6}$ : Job satisfaction relates positively to OCB.

$\mathrm{HO}_{7}$ : OCB does not relate positively to organisational commitment. / $\mathrm{H}_{7}$ : OCB relates positively to organisational commitment.

$\mathrm{HO}_{8}$ : Job dissatisfaction does not relate positively to counterproductive behaviour such as internet abuse. / $\mathrm{H}_{8}$ : Job dissatisfaction relates positively to counterproductive behaviour such as internet abuse.

$\mathrm{HO}_{9}$ : Flourishing does not indirectly affect organisational commitment, turnover intention, OCB and counterproductive behaviour. / $\mathrm{H}_{9}$ : Flourishing indirectly affects organisational commitment, turnover intention, OCB and counterproductive behaviour.

$\mathrm{HO}_{10}$ : Job satisfaction does not indirectly affect turnover intention and OCB. / $\mathrm{H}_{10}$ : Job satisfaction indirectly affects turnover intention and $O C B$.

\section{Method}

\section{Research design}

This study followed a descriptive, cross-sectional and quantitative approach and a non-random field survey design utilising questionnaires was used to gather data regarding the flourishing of information technology professionals and its outcomes (Field, 2009).

\section{Participants}

Due to practical considerations it was decided to target 450 information technology professionals in 10 organisations specializing in the development and implementation of information technology software in the Gauteng Province in South Africa. The response rate was 46\% $(N=205)$. Table 2 shows that a total of $69,3 \%$ of the sample comprised males, while $30,7 \%$ were females. The ages of the participants varied from 25 years to 65 years. A majority of $67.3 \%$ of the participants spoke Afrikaans and the majority of the participants (84,9\%) were white. Employment-related characteristics of the participants are reported in Table 3. The results in Table 3 show that more than $90 \%$ of the participants were employed on a permanent basis. A total of $66,8 \%$ worked more than 41 hours per week. Only 2,4\% reported that they played internet games at work.
Table 2: Characteristics of the participants $(N=205)$

\begin{tabular}{|c|c|c|c|}
\hline Item & Category & Frequency & Percentage \\
\hline Gender & $\begin{array}{l}\text { Male } \\
\text { Female }\end{array}$ & $\begin{array}{c}142 \\
63\end{array}$ & $\begin{array}{l}69,3 \\
30,7\end{array}$ \\
\hline Race & $\begin{array}{l}\text { White } \\
\text { African } \\
\text { Coloured } \\
\text { Indian } \\
\text { Other } \\
\end{array}$ & $\begin{array}{c}174 \\
23 \\
3 \\
4 \\
1 \\
\end{array}$ & $\begin{array}{c}84,9 \\
11,2 \\
1,5 \\
2,0 \\
, 5\end{array}$ \\
\hline Age & $\begin{array}{l}25 \text { years } \\
35 \text { years } \\
45 \text { years } \\
55 \text { years } \\
65 \text { years }\end{array}$ & $\begin{array}{c}55 \\
74 \\
53 \\
21 \\
2 \\
\end{array}$ & $\begin{array}{c}26,8 \\
36,1 \\
25,9 \\
10,2 \\
1,0 \\
\end{array}$ \\
\hline Tenure & $\begin{array}{l}1 \text { year } \\
2 \text { years } \\
3 \text { years } \\
4 \text { years } \\
5-9 \text { years } \\
10+\text { years }\end{array}$ & $\begin{array}{l}48 \\
25 \\
27 \\
23 \\
25 \\
57\end{array}$ & $\begin{array}{l}23,4 \\
12,2 \\
13,2 \\
11,2 \\
12,2 \\
27,8\end{array}$ \\
\hline $\begin{array}{l}\text { Marital } \\
\text { status }\end{array}$ & $\begin{array}{l}\text { Single/widow/widower } \\
\text { Married } \\
\text { Divorced } \\
\text { Remarried }\end{array}$ & $\begin{array}{c}65 \\
123 \\
12 \\
5\end{array}$ & $\begin{array}{c}31,7 \\
60,0 \\
5,9 \\
2,4\end{array}$ \\
\hline $\begin{array}{l}\text { Home } \\
\text { language }\end{array}$ & $\begin{array}{l}\text { Afrikaans } \\
\text { English } \\
\text { Other }\end{array}$ & $\begin{array}{c}138 \\
45 \\
22 \\
\end{array}$ & $\begin{array}{l}67,3 \\
22,0 \\
10,7\end{array}$ \\
\hline $\begin{array}{l}\text { Salary per } \\
\text { month }\end{array}$ & $\begin{array}{l}\text { Less than R10 } 000 \\
\text { R10 000 - R20 } 000 \\
\text { R20 000 - R40 000 } \\
\text { R40 000 - R60 } 000 \\
\text { R60 000 - R80 000 } \\
\text { R80 000 - R100 000 } \\
\text { R100 000+ }\end{array}$ & $\begin{array}{c}17 \\
48 \\
73 \\
33 \\
18 \\
9 \\
7 \\
\end{array}$ & $\begin{array}{c}8,3 \\
23,4 \\
35,6 \\
16,1 \\
8,8 \\
4,4 \\
3,4\end{array}$ \\
\hline
\end{tabular}

Table 3: Characteristics of the participants $(N=205)$

\begin{tabular}{l|l|c|c}
\hline \multicolumn{1}{c|}{ Item } & \multicolumn{1}{|c|}{ Category } & Frequency & Percentage \\
\hline Basis & Permanent & 187 & 91,2 \\
employed & Long term contract & 11 & 5,4 \\
& Hourly contract & 4 & 2,0 \\
& Other & 3 & 1,5 \\
\hline Work hours & Up to 10 & 1 & 0,5 \\
per week & $21-30$ & 1 & 0,5 \\
& $31-40$ & 66 & 32,2 \\
& $41-50$ & 113 & 55,1 \\
& 51 or more & 24 & 11,7 \\
\hline Overtime & 5 & 133 & 64,9 \\
hours per & 10 & 55 & 26,8 \\
week & 15 & 10 & 3,4 \\
& 20 & 5 & 4,9 \\
\hline Playing & Yes & 200 & 2,4 \\
internet & No & & 97,6 \\
games at & & & \\
work & & &
\end{tabular}

\section{Measuring instruments}

In this study, the following measuring instruments were used: the Mental Health Continuum Short Form, Organisational Commitment Scale, Turnover Intention Scale, Organisational Citizenship Behaviour Scale and Job Satisfaction Scale. 
The Mental Health Continuum Short Form (MHC-SF; Keyes, 2009) was used to measure flourishing. The MHCSF consists of 14 items measuring three dimensions, namely emotional well-being (three items, "During the past month, how often did you feel happy?"), social well-being (five items, "During the past month, how often did you feel that you had something important to contribute to society?”), and psychological well-being (six items, "During the past month, how often did you feel that you liked most parts of your personality?”). Response options ranged from 1 (never) to 6 (every day). Nationally representative samples of US adults and college students confirmed the three factor structure of the long and short forms of the MHC emotional, psychological, and social well-being, and results have shown excellent internal consistency $(>0,80)$ in studies in the U.S., the Netherlands and in South Africa (Keyes, 2009; Keyes et al., 2008).

The Job Satisfaction Scale (JSS; Rothmann, 2010) was used to measure job satisfaction. Three items measured how satisfied individuals felt with their jobs (e.g., "I feel fairly satisfied with my present job"; and "I find real enjoyment in my work"). Response options ranged from 1 (totally disagree) to 5 (totally agree). The Cronbach alpha coefficient for the JSS was 0,84.

Organisational commitment was measured by the Organisational Commitment Scale (OCS; Rothmann, 2010). Six items measured attachment (loyalty; "I feel personally attached to my work organisation"), and pride (identification; "I feel proud to be an employee of this organisation”). Response options ranged from 1 (strongly disagree) to 7 (strongly agree). The Cronbach alpha coefficient for the OCS was 0,85 .

The Turnover Intention Scale (TIS; Sjöberg \& Sverke, 2000) was used to measure the intention to leave. The TIS consisted of three items and an example of an item is "If I was completely free to choose, I would leave this job". Response options ranged from 1 (strongly disagree) to 5 (strongly agree). The TIS reported a Cronbach alpha coefficient of 0,83 .

A measure of counterproductive work behaviour of information technology professionals was developed for the purposes of this study. A definition of counterproductive work behaviour was provided to line managers who were familiar with the specific jobs. Line managers were then asked to generate example behaviours relevant to the jobs in question that were consistent with counterproductive work behaviour. Three items were then developed to measure counterproductive work behaviour ("I use the internet more than I ought to", "My use of the internet sometimes seems beyond my control" and "People complain that I use the internet too much"). Participants rated the items on a frequency scale varying from 1 (never) to 5 (every day).

The Organisational Citizenship Behaviour Scale (OCBS, Rothmann, 2010) was utilised to measure organisational citizenship behaviour. The OCBS consisted of six items, three which measured assistance to co-workers in the organisation ("I give up time to help co-workers who have work or non-work problems”) and three which measured assistance to the organisation ("I take action to protect the organisation from potential problems”). Response options ranged from 1 (strongly disagree) to 7 (strongly agree). The Cronbach alpha coefficients for the two scales were 0,78 (assistance to co-workers) and 0,80 (assistance to the organisation).

\section{Research procedure}

The researchers administered a survey questionnaire to the participants electronically. The questionnaire was accompanied by a cover letter explaining the purpose and emphasising the confidentiality of the research project. Managers from various information technology organisations were contacted to introduce the research topic to them and to obtain permission from them to involve their employees in the project. Respondents were assured that their participation was anonymous and voluntary and that they could withdraw at any stage. From May 2011 until July 2011 questionnaires were made available online. The raw data was captured and converted to an SPSS dataset.

\section{Statistical analyses}

Structural equation modelling (SEM) methods as implemented in AMOS (Arbuckle, 2009) were used to test the measurement and structural models. The following indices produced by AMOS were used in this study: a) absolute fit indices, including the Chi-square statistic, which is the test of absolute fit of the model, the Standardized Root Mean Residual (SRMR) and the Root-Means-Square Error of Approximation (RMSEA), b) incremental fit indices, including the Tucker-Lewis Index (TLI) and the Comparative Fit Index (Hair, Black, Babin \& Andersen, 2010). TLI and CFI values higher than 0,90 are considered acceptable. RMSEA values lower than 0,05 and a SRMR lower than 0,08 indicate a close fit between the model and the data. Descriptive statistics (means and standard deviations) and Pearson correlations were computed using the SPSS19 program (SPSS, 2011). The level of statistical significance was set at $p<0,05$.

\section{Results}

\section{Testing the measurement model}

Structural equation modelling (SEM) methods, as implemented by AMOS (Arbuckle, 2009), were used to test the measurement model. Global assessments of model fit were based on several goodness-of-fit statistics (CFI, TLI, RMSEA and RMSR).

\section{Hypothesised models}

In the hypothesised models each of the observed variables loaded on only one latent factor. The observed variables in the model were treated as continuous variables. Errors of measurement associated with observed variables were 
uncorrelated while latent variables were allowed to correlate.

The following nested measurement models were tested:

- Model 1: A three-factor model of flourishing consisting of three first-order latent factors, namely emotional well-being (three items), social well-being (five items) and psychological well-being (six items) with five further latent factors representing organisational and individual outcomes, including turnover intention (three items), organisational commitment (six items), counterproductive behaviour (three items), job satisfaction (three items) and organisational citizenship behaviour (four items).

- Model 2: A one-factor model of flourishing (consisting of 14 observed variables) and five latent factors representing organisational and individual outcomes, including turnover intention (three items), organisational commitment (six items), counterproductive behaviour (three items), job satisfaction (three items) and organisational citizenship behaviour (four items).

- Model 3: A three-factor model of flourishing consisting of three first order latent factors, namely emotional well-being (three items), social well-being (five items) and psychological well-being (six items) with two latent factors representing organisational outcomes (turnover intention - three items; organisational commitment - six items and organisational citizenship behaviour four items) and individual outcomes (counterproductive behaviour - three items and job satisfaction - three items).

- $\quad$ Model 4: A one-factor model of flourishing (consisting of 14 observed variables) and two latent factors representing organisational outcomes (turnover intention - three items; organisational commitment six items and organisational citizenship behaviour four items) and individual outcomes (counterproductive behaviour - three items and job satisfaction - three items).

- Model 5: A one-factor model of flourishing including all variables, namely emotional well-being (three items), social well-being (five items), psychological well-being (six items), organisational and individual outcomes including turnover intention (three items), organisational commitment (six items), counterproductive behaviour (three items), job satisfaction (three items) and organisational citizenship behaviour (four items). In a cross-sectional survey a common method variance can be a problem as the multiple data in one questionnaire is very closely related. Therefore, the one-factor model was tested.

Table 4 presents fit statistics for the test of the various models.

Table 4: Fit statistics of competing measurement models

\begin{tabular}{c|c|c|c|c|c|c|c|c}
\hline Model & $\chi^{2}$ & $d f$ & TLI & CFI & RMSEA & SRMR & AIC & BIC \\
\hline Model 1 & 839,99 & 477 & 0,89 & 0,90 & 0,06 & 0,06 & 1007,98 & 1041,59 \\
\hline Model 2 & 1030,59 & 480 & 0,83 & 0,85 & 0,08 & 0,07 & 1192,59 & 1224,99 \\
\hline Model 3 & 1314,05 & 489 & 0,76 & 0,77 & 0,09 & 0,09 & 1458,05 & 1486,85 \\
\hline Model 4 & 1504,83 & 492 & 0,70 & 0,72 & 0,10 & 0,09 & 1642,84 & 1670,44 \\
\hline Model 5 & 2237,23 & 495 & 0,49 & 0,52 & 0,13 & 0,12 & 2369,23 & 2395,63 \\
\hline
\end{tabular}

$d f=$ degrees of freedom; TLI= Tucker-Lewis Index; CFI= Comparative Fit Index; RMSEA= Root Mean Square Error of Approximation; SRMR= Standardised Root Mean Square Residual; AIC = Akaike Information Criterion; BIC = Bayes Information Criterion

Two fit statistics, namely the Akaike Information Criterion (AIC) and Bayes Information Criterion (BIC) were used in addition to other fit indices in this study. The AIC, which is a comparative measure of fit, is meaningful when different models are estimated. The lowest AIC is the best fitting model. The BIC provides an indication of model parsimony (Kline, 2010). Comparison of the fit indices indicates that Model 1 fitted the data best. The other four models showed a poor fit to the data.

The first model hypothesised that flourishing consists of three first-order latent factors, namely emotional well-being (3 items), social well-being (5 items) and psychological well-being (6 items), one latent second-order factor, namely flourishing and five first-order latent factors, namely turnover intention (three items), organisational commitment (six items), counterproductive behaviour (internet abuse three items), job satisfaction (three items) and organisational citizenship behaviour (four items). It was assumed that the errors of items are uncorrelated. The model was over- identified: It had 561 distinct sample moments, 84 distinct parameters to be estimated and 477 degrees of freedom.

The standardised regression coefficients were all statistically significant $(p<0,01)$. The weights for flourishing ranged from 0,72 to 0,99 , whereas emotional well-being ranged from the lowest weight 0,78 to the highest of 0,90 . Social well-being ranged from 0,60 to 0,80 , whilst psychological well-being ranged from 0,55 to 0,82 . The lowest weight for organisational commitment was 0,69 and the highest was 0,84; counterproductive behaviour (internet) reported the lowest weight of 0,64 ranging to 0,81 . Weights for organisational citizenship behaviour varied from 0,57 to 0,82 ; job satisfaction varied from $-0,63$ to 0,93 , whilst turnover intention ranged from the lowest weight being $-0,55$ to the highest weight of 0,87 . 


\section{Testing the structural model}

The descriptive statistics and alpha coefficients of the measuring instruments after adapting the measurement model are reported in Table 5. The results in Table 5 show that all the scales had acceptable alpha coefficients $(>0,70)$ (see Nunnally \& Bernstein, 1994).

The structural revised model showed acceptable fit: $\chi^{2}=$ $864,21, d f=484$, TLI $=0,89$, CFI $=0,90$, RMSEA $=0,06$ and SRMR $=0,07$, although it is clear that the model fit could be improved (TLI $<0,90$ ).

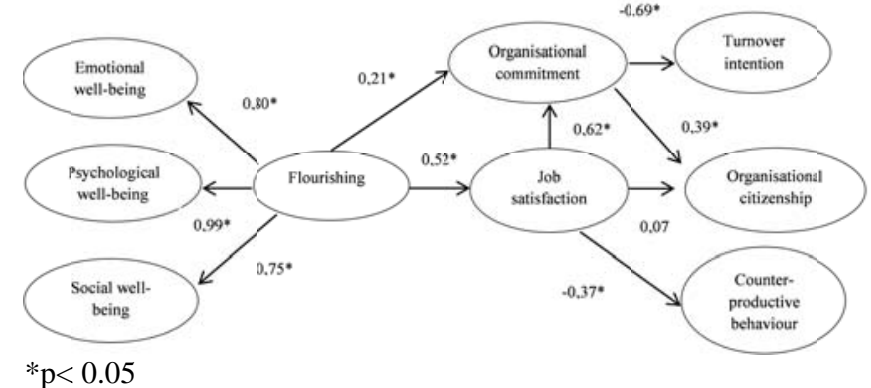

Figure 1: Maximum likelihood estimates for the hypothesized model of flourishing

Table 5: Descriptive statistics, alpha coefficients and Pearson correlations of the scales $(N=205)$

\begin{tabular}{|c|c|c|c|c|c|c|c|c|c|c|c|}
\hline Variable & Mean & $S D$ & $\alpha$ & 1 & 2 & 3 & 4 & 5 & 6 & 7 & 8 \\
\hline 1. MHC: TOTAL & 3.11 & 0.85 & 0.91 & - & - & - & - & - & - & - & - \\
\hline MHC: EWB & 3.49 & 0.93 & 0.87 & $0.78^{* *}$ & - & - & - & - & - & - & - \\
\hline 3. MHC: SWB & 2.48 & 1.09 & 0.82 & $0.87^{* *}$ & $0.51^{* *}$ & - & - & - & - & - & - \\
\hline MHC: PWB & 3.44 & 0.90 & 0.86 & $0.91^{* *}$ & $0.68^{* *}$ & $0.64^{* *}$ & - & - & - & - & - \\
\hline Job Satisfaction & 3.64 & 0.76 & 0.84 & $0.42^{* *}$ & $0.42^{* *}$ & $0.28^{* *}$ & $0.43^{* *}$ & - & - & - & - \\
\hline $\begin{array}{l}\text { 6. Organisational } \\
\text { Commitment }\end{array}$ & 3.70 & 0.70 & 0.90 & $0.49^{* *}$ & $0.35^{* *}$ & $0.40^{* *}$ & $0.49^{* *}$ & $0.63^{* *}$ & - & - & - \\
\hline $\begin{array}{l}\text { 7. Counterproductive } \\
\text { Behaviour }\end{array}$ & 1.03 & 1.02 & 0.74 & -0.13 & $-0.15^{*}$ & -0.04 & $-0.17^{*}$ & $-0.38^{* *}$ & $-0.28^{* *}$ & - & - \\
\hline 8. OCB & 3.54 & 1.17 & 0.81 & $0.36^{* *}$ & $0.24^{* *}$ & $0.30^{* *}$ & $0.36^{* *}$ & $0.23^{* *}$ & $0.36^{* *}$ & -0.01 & - \\
\hline 9. Turnover Intention & 2.34 & 0.88 & 0.79 & $-0.25^{* *}$ & $-0.22^{* *}$ & $-0.16^{*}$ & $-0.27^{* *}$ & $-0.66^{* *}$ & $-0.60^{* *}$ & $0.23^{* *}$ & -0.11 \\
\hline
\end{tabular}

* Correlation is significant at the 0.05 level (2-tailed)

** Correlation is significant at the 0.01 level (2-tailed)

\section{Evaluating the proposed model}

Figure 1 shows the standardized path coefficients estimated by AMOS for the proposed theoretical model.

\section{Hypothesis 1}

All path coefficients predicting flourishing were significant and had the expected sign. Flourishing had a significant positive relation with job satisfaction $\left(R^{2}=0,65\right)$. $\mathrm{HO}_{1}$ is therefore rejected and $\mathrm{H}_{1}$ is accepted.

\section{Hypotheses 2 and 3}

For the portion of the model predicting organisational commitment, the path coefficient was significant and had the expected sign. Job satisfaction and flourishing had significant and positive relations with organisational commitment $\left(R^{2}=0,33\right)$. $\mathrm{HO}_{2}$ and $\mathrm{HO}_{3}$ are therefore rejected and $\mathrm{H}_{2}$ and $\mathrm{H}_{3}$ are accepted.

\section{Hypothesis 4}

For the portion of the model predicting turnover intention, the path coefficient was significant and had the expected sign. Organisational commitment had a significant and negative relation with turnover intention $\left(R^{2}=0,69\right) . \mathrm{HO}_{4}$ is therefore rejected and $\mathrm{H}_{4}$ is accepted.

\section{Hypothesis 6}

Job satisfaction did not have a significant positive relation with organisational citizenship behaviour. Therefore $\mathrm{H}_{6}$ cannot be rejected and $\mathrm{H}_{6}$ is rejected.

\section{Hypothesis 7}

Organisational commitment had a significant positive relation with organisational citizenship behaviour $\left(R^{2}=\right.$ $0,15) . \mathrm{HO}_{7}$ is therefore rejected and $\mathrm{H}_{7}$ is accepted.

\section{Hypothesis 8}

For the portion of the model predicting counterproductive behaviour (internet abuse), the path coefficient was significant and had the expected sign. Job dissatisfaction had a negatively significant relation with internet abuse. The ML-estimated equation accounted for a moderate proportion of variance in counterproductive behaviour $\left(R^{2}=0,37\right)$. $\mathrm{H}_{8}$ is therefore rejected and $\mathrm{H}_{8}$ is accepted.

It was hypothesised that job satisfaction would mediate the relationships between flourishing and individual and organisational outcomes (hypotheses 9 and 10). To meet the conditions for mediation (as described by Preacher \& Hayes, 2008, 2009), three different models using the AMOS18 program (Arbuckle, 2009) were analysed. The three competing models were as follows: a) Model 1 ('Indirect effects' model) estimated paths from the independent variable to its hypothesized mediator and from each mediator to turnover intention, organisational citizenship behaviour and counterproductive behaviour (internet abuse). b) Model 2 ('Direct effects' model) estimated direct paths from the independent variable to its hypothesized mediator and to organisational commitment. c) Model 3 ('Full' model) estimated direct and indirect paths from the independent variable to its proposed mediator and outcome variables. 
Path analysis was used to examine the fit of these models to the data. Because the indirect effects model and the direct effects model are both hierarchically nested within the full model, differences in fit can be determined using the chisquare (i.e. $\Delta \chi^{2}$ ) test described by Kline (2010). The fit statistics for the different models are reported in Table 6 . The significant $\chi^{2}$ difference tests indicate that the hypothesized model (Model 1) has a better overall fit to the data than the direct effects model $\left(\Delta \chi^{2}=85,47, \Delta d f=41 p<\right.$ 0,01 ). However, the full model (Model 3) has a better overall fit than the indirect effects model (Model 1; $\Delta \chi^{2}=$ $51,80, \Delta d f=4, p<0,01)$. This suggests that mediation as conceived in the original theoretical framework does not explain the covariation in the data better than a model allowing partial mediation (i.e. Model 3). When the direct path between flourishing and turnover intention is added to the framework, the relationship between organisational commitment and turnover intention becomes positive. The relations between flourishing on the one hand and organisational commitment and turnover intention on the other hand, are all statistically significant $(p<0,01)$. Table 6 reports the fit indices and path coefficients for Models 1, 2 and 3.

\section{Revised model}

Given that the full model fit the data better than the originally theorised model, it was decided to examine whether a revised model based on the original framework could improve its explanatory power and overall fit with the data. The paths which were not statistically significant in the revised model were deleted. The revised model showed acceptable fit: $\chi^{2}=818,14, d f=483$, TLI $=0,90$, CFI $=$ 0,91 , RMSEA $=0,06$ and SRMR $=0,07$. The nonsignificant chi-squared difference tests after these path deletions indicated that removal of these paths did not significantly affect the model's degree of overall fit $\left(\Delta \chi^{2}=\right.$ 5,73, $\Delta d f=3, p>0,01)$. Compared with the hypothesized model, the revised model still showed a statistically significant improvement $\left(\Delta \chi^{2}=46,07, \Delta d f=1, p<0,01\right)$. The final model is given in Figure 2.
Table 6: Initial framework fit indices and standardized path coefficients

\begin{tabular}{|c|c|c|c|c|}
\hline \multicolumn{2}{|l|}{ Measures } & \multirow{2}{*}{ 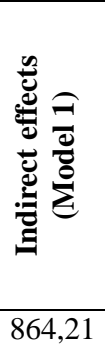 } & \multirow{2}{*}{ 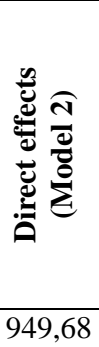 } & \multirow{2}{*}{ 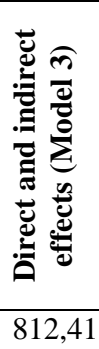 } \\
\hline \multirow[t]{6}{*}{ Fit Indices } & $\chi^{2}$ & & & \\
\hline & $d f$ & 484 & 483 & 480 \\
\hline & TLI & 0,89 & 0,86 & 0,90 \\
\hline & CFI & 0,90 & 0,87 & 0,91 \\
\hline & RMSEA & 0,06 & 0,07 & 0,06 \\
\hline & SRMR & 0,07 & 0,16 & 0,06 \\
\hline \multirow{3}{*}{$\begin{array}{l}\text { Direct Effects on } \\
\text { Turnover } \\
\text { Intention }\end{array}$} & Flourishing & - & $-0,70^{*}$ & $0,18 *$ \\
\hline & $\begin{array}{l}\text { Organisational } \\
\text { commitment }\end{array}$ & $-0,69 *$ & $-0,34^{*}$ & $-0,26 *$ \\
\hline & $\begin{array}{l}\text { Job } \\
\text { satisfaction }\end{array}$ & - & $-0,73^{*}$ & $-0,66^{*}$ \\
\hline \multirow{2}{*}{$\begin{array}{l}\text { Direct Effects on } \\
\text { Organisational } \\
\text { Commitment }\end{array}$} & Flourishing & $0,20^{*}$ & $0,84^{*}$ & $0,22 *$ \\
\hline & $\begin{array}{l}\text { Job } \\
\text { satisfaction }\end{array}$ & $0,66^{*}$ & - & $0,62 *$ \\
\hline $\begin{array}{l}\text { Direct Effects on } \\
\text { Job Satisfaction }\end{array}$ & Flourishing & $0,52 *$ & $0,85 *$ & $0,52 *$ \\
\hline \multirow{4}{*}{$\begin{array}{l}\text { Direct Effects on } \\
\text { Counterproductive } \\
\text { Behaviour }\end{array}$} & Flourishing & - & $-0,35^{*}$ & 0,03 \\
\hline & $\begin{array}{l}\text { Job } \\
\text { satisfaction }\end{array}$ & $-0,37 *$ & $-0,38^{*}$ & $-0,38^{*}$ \\
\hline & $\begin{array}{l}\text { Organisational } \\
\text { commitment }\end{array}$ & - & - & - \\
\hline & $\begin{array}{l}\text { Organisational } \\
\text { citizenship }\end{array}$ & - & - & - \\
\hline \multirow{3}{*}{$\begin{array}{l}\text { Direct Effects on } \\
\text { Organisational } \\
\text { Citizenship } \\
\text { Behaviour }\end{array}$} & Flourishing & - & $0,46^{*}$ & $0,28 *$ \\
\hline & $\begin{array}{l}\text { Organisational } \\
\text { commitment }\end{array}$ & $0,39 *$ & - & $0,31 *$ \\
\hline & $\begin{array}{l}\text { Job } \\
\text { satisfaction }\end{array}$ & 0,07 & - & $-0,03$ \\
\hline
\end{tabular}

To determine whether any relationships in the revised model were indeed mediated by job satisfaction and organisational commitment, the indirect effects of the independent variables via the proposed mediators were computed. The procedures were described by Hayes (2009) to determine whether the indirect effects were different from zero. Bootstrapping was used to construct two-sided biascorrected confidence intervals so as to evaluate mediation effects (see Table 7). 
Table 7: Indirect effects of flourishing and job satisfaction

\begin{tabular}{|c|c|c|c|c|c|c|}
\hline \multirow[t]{2}{*}{ Variable } & \multicolumn{3}{|c|}{ Flourishing } & \multicolumn{3}{|c|}{ Job Satisfaction } \\
\hline & 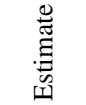 & 된 & $\begin{array}{l}\text { Ũ } \\
\text { ᄋे }\end{array}$ & 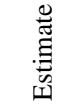 & 完 & $\begin{array}{l}\text { Ũ } \\
\text { ᄋे }\end{array}$ \\
\hline $\begin{array}{l}\text { Organisational } \\
\text { Commitment }\end{array}$ & $0,31 *$ & 0,05 & $\begin{array}{l}{[0,24,} \\
0,40]\end{array}$ & - & - & - \\
\hline $\begin{array}{l}\text { Turnover } \\
\text { Intention }\end{array}$ & $-0,41^{*}$ & 0,05 & $\begin{array}{l}{[-0,50,} \\
-0,33]\end{array}$ & $-0,12^{*}$ & 0,07 & $\begin{array}{l}{[-0,23,} \\
-0,02]\end{array}$ \\
\hline $\begin{array}{l}\text { Organisational } \\
\text { Citizenship } \\
\text { Behaviour }\end{array}$ & $0,16^{*}$ & 0,05 & $\begin{array}{c}{[0,08,} \\
0,25]\end{array}$ & $0,18^{*}$ & 0,06 & $\begin{array}{c}{[0,09,} \\
0,29]\end{array}$ \\
\hline $\begin{array}{l}\text { Counter- } \\
\text { productive } \\
\text { Behaviour }\end{array}$ & $-0,18^{*}$ & 0,05 & $\begin{array}{c}{[-0,27,} \\
-0,11]\end{array}$ & - & - & - \\
\hline
\end{tabular}

Table 7 shows that the bootstrap estimated indirect effects of flourishing on organisational commitment, turnover intention, organisational citizenship behaviour and counterproductive behaviour were statistically significant ( $p$ $<0,01)$ and different from zero (Preacher \& Hayes, 2008). Furthermore, the bootstrap estimated indirect effects of job satisfaction on turnover intention and organisational citizenship behaviour were statistically significant $(p<0,01)$ and different from zero. Therefore, $\mathrm{HO}_{5}, \mathrm{HO}_{9}$ and $\mathrm{HO}_{10}$ are rejected and $\mathrm{H}_{5}, \mathrm{H}_{9}$ and $\mathrm{H}_{10}$ are accepted.

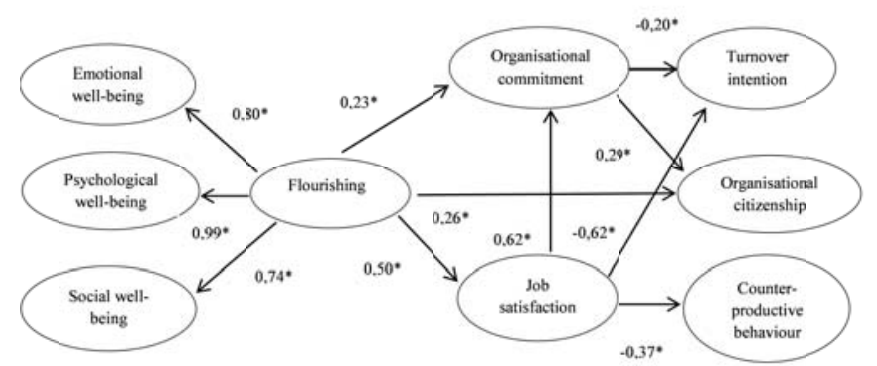

Figure 2: Maximum likelihood estimates for the revised model of flourishing (standardized solution)

Taken together, the model fit indices suggest that the relationships posited in the revised model (see Figure 2) account for a substantial amount of the covariation in the data. The revised model accounts for a large proportion of the variance in the mediators (27\% and $58 \%$ of the variance in job satisfaction and organisational commitment respectively) and in the dependent variables, namely turnover intention (62\%), organisational citizenship behaviour (24\%) and counterproductive behaviour (13\%), lending more empirical support for the revised model's fit.

\section{Discussion}

The aim of this study was to investigate the relationship between flourishing and individual and organisational outcomes such as job satisfaction, organisational commitment, organisational citizenship behaviour, turnover intention and counterproductive behaviour. The results provided support for a model in which flourishing (i.e. emotional, psychological and social well-being) of employees had both direct and indirect effects on individual and organisational outcomes. Flourishing of IT professionals had a direct positive effect on their job satisfaction, which in turn had a strong positive effect on their organisational commitment and a negative effect on their turnover intention. Job satisfaction also affected counterproductive work behaviour directly and negatively. Flourishing affected organisational citizenship behaviour directly and positively as well as indirectly (through organisational commitment). Flourishing affected organisational commitment indirectly (through a positive effect on job satisfaction), while it affected turnover intention indirectly (through a reversed effect on job dissatisfaction and a lack of organisational commitment).

Flourishing was strongly related to job satisfaction in this study (27\% of the variance shared). Psychological wellbeing contributed most to flourishing in the model, followed by emotional well-being and social well-being. Therefore, employees who were emotionally, psychologically and socially well were also more satisfied with their jobs. This is in line with findings in studies by Connolly and Viswesvaran (2000), Pierce and Gardner (2004). This result supports the finding of Lyubomirsky et al. (2005) regarding the relation between positive affect and job satisfaction. According to the part-whole theory of Bowling et al. (2010), job satisfaction is strongly affected by an individual's level of subjective well-being.

Flourishing had a strong relation with organisational commitment. However, the structural model showed that flourishing affected organisational commitment directly, but most strongly through its relationship with job satisfaction (an indirect effect). This finding suggests that employees who flourish, experience higher levels of job satisfaction, which result in their being more committed to the organisation. Flourishing also had a direct effect on the commitment of employees, although the effect was small.

Job satisfaction had important effects in the structural model in this study. Flourishing affected organisational commitment moderately through its effect on job satisfaction, but also affected turnover intention strongly (indirectly) through its effects on job satisfaction and organisational commitment. IT professionals who were satisfied with their jobs showed more commitment towards their organisation. Employees who were less committed to the organisation showed a higher level of turnover intention. Meyer and Allen (1997) and Harrison and Hubbard (1998) also found a significant relation between job satisfaction and organisational commitment. However, job dissatisfaction also affected turnover intention directly and strongly.

The results are in line with both the spillover theory, which postulates that a positive outcome has a positive effect on another outcome, and a negative effect will have negative spillover on another outcome, and the expansionist theory, which states that one role increases resources for other roles (Hecht \& Boies, 2009). These theories support the finding in 
this study that IT professionals with lower job satisfaction tend to engage in counterproductive behaviour, such as internet abuse and playing games (Woon \& Pee, 2004). Linking to the part-whole theory as well as the spillover and expansionist theories, is Fredrickson's (1998) broaden-andbuild theory that states that positive emotions in IT professionals will intensify their personal resources which in turn will predict their future well-being (Ouwencel et al., 2011). Lyubomirsky, Sheldon and Schkade (2005) propose that such resources enable individuals to thrive and succeed at work, in relationships and with health. An individual who feels well is more likely to function well, both psychologically and socially, which means meeting the criterion for positive mental health as flourishing. Thus, it was found that flourishing has an influence on all individual and organisational outcomes in this study, in that flourishing has a direct effect on the following aspects: on job satisfaction; on organisational commitment with job satisfaction as partial mediator; on counterproductive behaviour with job satisfaction fully mediating the relationship; on turnover intention; and OCB with organisational commitment partially mediating the relationship.

The results of this study showed that job satisfaction did not have a direct effect on OCB. However, it had a small effect on OCB through its relation with organisational commitment. Employees who were satisfied with their jobs, showed higher levels of organisational commitment, which in turn affected on their willingness to be helpful towards others in the organisation and generally do more than what the job requires. One would expect satisfied employees to reciprocate their positive experiences and from evidence in the psychological literature persons who experience positive affect tend to engage in prosocial behaviours (Clark \& Isen, 1982). Several studies produced results suggesting that job satisfaction relates positively and significantly with OCB (Bateman \& Organ, 1983; Puffer, 1987). However, Schnake, Cochran and Dumler (1995) found that job satisfaction accounted for the variance in only two of the five OCB dimensions.

The results indicated that flourishing individuals engaged in citizenship behaviour by doing things for the organisation and other individuals outside the parameters of their jobs. Languishing employees, those who do not function optimally on social, emotional and psychological dimensions, engage less in citizenship behaviour besides being dissatisfied with their jobs and lacking commitment towards the organisation. Employees engaging in citizenship behaviour do so because they probably believe that they could make a difference. This argument links perfectly with the part-whole theory (Bowling et al., 2010). An accumulation of emotional well-being (positive affect and satisfaction with life), psychological well-being (having a purpose in life and positive relations with others) and social well-being (exhibiting positive social functioning) (Keyes, 2007) seems to have a moderate direct effect on OCB.

It can be concluded that flourishing strongly affects job satisfaction, while job satisfaction affects organisational commitment and turnover intention. The findings emphasise the important relationship between flourishing and individual and organisational outcomes. Therefore, flourishing employees in the IT industry seem to be to the benefit of not only the individual's well-being, but also to the benefit of the organisation (Sparks et al., 2001). This study had various limitations. First, due to the crosssectional design used in the study, causal relationships cannot be ascertained. However, Lyubomirsky et al. (2005) and Bowling et al. (2010) present strong evidence that job satisfaction and positive organisational outcomes result because of well-being. Second, the sample size was relatively small compared to the number of variables used. Despite its size, however, the sample in this study is representative of a very important, distinguished and scarce category of information technology professionals.

\section{Recommendations}

This study showed that flourishing is positively associated with individual and organisational outcomes. Therefore, it is necessary to understand the nature and etiology of the strengths and competencies of flourishing people to promote their mental health (Keyes, 2002). Interventions should be implemented to promote flourishing of IT professionals. Not only emotional well-being, but also psychological and social well-being should be the focus of interventions. Cognitivebehavioural processes, interpersonal attachment, coping and meaning-making of individuals should be addressed to promote their flourishing (Keyes, 2005). The effective management and promotion of employee well-being which spills over into organisational health should form the cornerstones towards successful human resources and business practices. Policies about health-promotion programmes should not only be aimed at reducing IT employees' counterproductive behaviour at work, focusing on psychological disorders, but should primarily be set on enhancing and developing employees' well-being, strengths and positive emotions, as well as creating an appropriate environment conducive to positive interpersonal, group and organisational outcomes through including training programmes on, amongst others, growth group experiences (developing employees' self-actualisation); skills training for groups (including problem-solving, conflict management, communication and assertive behaviour); and team-building exercises that promote employee well-being through developing social networks amongst employees (Bergh \& Theron, 2012). Future studies should employ longitudinal panel as well as experimental designs to study the causality of relationships between flourishing and individual and organisational outcomes. Interventions to promote flourishing should be developed and evaluated. Furthermore, objective measures should be developed to assess the flourishing of employees.

\section{References}

Arbuckle, J.L. 2009. Amos 18.0. Crawfordville, FL: AMOS Development Corporation. 
Armstrong, M. 2006. A handbook of human resource management practice (10 ${ }^{\text {th }}$ Edition). London: Kogan Page.

Bakker, A.B. \& Schaufeli, W.B. 2008. 'Positive organizational behavior: Engaged employees in flourishing organizations', Journal of Organizational Behavior, 29: 147-154.

Bakker, A.B., Demerouti, E. \& Schaufeli, W.B. 2003. 'Dual processes at work in a call centre: An application of the JobDemands Resources Model', European Journal of Work and Organizational Psychology, 12: 393-417.

Bateman, T.S. \& Organ, D.W. 1983. 'Job satisfaction and the good soldier: The relationship between affect and citizenship', Academy of Management Journal, 26: 587595.

Blau, P. 1964. Exchange and power in social life. New York: Wiley.

Bergh, Z.C. \& Theron, A.L. 2012. Psychology in the work context ( $4^{\text {th }}$ Edition). Cape Town: Oxford University Press.

Bono, J.E., Davies, S.E. \& Rasch, R.L. 2012. 'Some traits associated with flourishing at work'. In Cameron, K. \& Spreitzer, G.M. (Eds.). The Oxford handbook of positive organizational scholarship. New York: Oxford University Press, p.p. 125-137.

Bowling, N.A., Eschleman, K.J. \& Wang, Q. 2010. 'A metaanalytic examination of the relationship between job satisfaction and subjective well-being', Journal of Occupational and Organizational Psychology, 83: 915-934.

Chang, M.K. \& Cheung, W. 2001. 'Determinants of the intention to use internet/WWW at work: A confirmatory study', Information and Management, 39: 1-14.

Clark, M.S. \& Isen, A.M. 1982. 'Toward understanding the relationship between feeling states and social behaviour.' In Hastrof, A.H. \& Isen, A.M. (Eds.). Cognitive social psychology. New York: Elsevier, p.p. 73-108.

Cohen, A. 2003. Multiple commitments in the workplace: An integrative approach. London: Lawrence Erlbaum Associates.

Connolly, J.J. \& Viswesvaran, C. 2000. 'The role of affectivity in job satisfaction: A meta-analysis', Personality and Individual Differences, 29: 265-281.

Coyle-Shapiro, J.A. 2002. 'A psychological contract perspective on organizational citizenship behavior', Journal of Organizational Behavior, 23: 927-946.

Coyle-Shapiro, J.A. \& Kessler, I. 2002. 'Contingent and non-contingent working in local government: Contrasting psychological contracts', Public Administration, 80: 77101.
Deci, E.L. \& Ryan, R.M. 2008. 'Self-determination theory: A macrotheory of human motivation, development, and health', Canadian Psychology, 49(3): 182-185.

De Cuyper, N. \& De Witte, H. 2007. 'Job insecurity among temporary versus permanent workers: Effects on job satisfaction, organizational commitment, life satisfaction and self-rated performance', Work and Stress, 21: 65-84.

De Cuyper, N., Bernhard-Oettel, C., Berntson, E., De Witte, H. \& Alarco, B. 2008. 'Employability and employees' wellbeing: Mediation by job insecurity', Applied Psychology: An International Review, 57: 488-509.

Diener, E. 1984. 'Subjective well-being', Psychological Bulletin, 95: 542-575.

Diener, E., Kesebir, P. \& Lucas, R. 2008. 'Benefits of accounts of well-being - For societies and for psychological science', Applied Psychology: An International Journal, 57: 37-53.

Field, A. 2009. Discovering statistics using SPSS $\left(3^{\text {rd }}\right.$ Edition). Los Angeles, CA: SAGE.

Fredrickson, B.L. 1998. 'What good are positive emotions?' Review of General Psychology, 2: 300-319.

Fredrickson, B.L. 2001. 'The role of positive emotions on positive psychology: The broaden-and-build theory of positive emotions', American Psychological Association, 56: $218-226$.

Fredrickson, B.L. 2004. 'The broaden-and-build theory of positive emotions', Philosophical Transaction: Biological Sciences, 359: 1367-1377.

Gaylard, M., Sutherland, M. \& Viedge, C. 2005. 'The factors perceived to influence the retention of information technology workers', South African Journal of Business Management, 36: 87-97.

Hair, J.F., Black, W.C., Babin, B.J. \& Andersen, R.E. 2010. Multivariate data analysis: A global perspective. Upper Saddle River, NJ: Person.

Harrison, J.K. \& Hubbard, R. 1998. 'Antecedents to organisational commitment among Mexican employees of a U.S. firm in Mexico', The Journal of Social Psychology, 138: 609-623.

Harter, J.K., Schmidt, F.L. \& Hayes, T.L. 2002. 'Businessunit level relationship between employee satisfaction, employee engagement, and business outcomes: A metaanalysis', Journal of Applied Psychology, 87: 268-279.

Harter, J.K., Schmidt, F.L. \& Keyes, C.L.M. 2002. 'Wellbeing in the workplace and its relationship to business outcomes: A review of the Gallup Studies'. In Keyes, C.L.M. \& Haidt, J. (Eds.). Flourishing: The positive person 
and the good life. Washington, DC: American Psychological Association, p.p. 205-224.

Hayes, A.F. 2009. 'Beyond Baron and Kenny: Statistical mediation analysis in the new millennium', Communication Monographs, 76: 408-420.

Hecht, D.H. \& Boies, K. 2009. 'Structure and correlates of spillover from nonwork to work: An examination of nonwork activities, well-being, and work outcomes', Journal of Organizational Health Psychology, 14: 414-426.

Judge, T.A., Van Vianen, A.E.M. \& De Pater, I. 2004. 'Emotional stability, core self-evaluations, and job outcomes: A review of the evidence and an agenda for future research', Human Performance, 17: 325-346.

Keyes. C.L.M. 2002. 'The mental health continuum: From languishing to flourishing in life', Journal of Health and Social Behavior, 43: 207-222.

Keyes, C.L.M. 2005. 'Mental illness and/or mental health? Investing axioms of the complete state model of health', Journal of Consulting and Clinical Psychology, 73: 539548.

Keyes, C.L.M. 2007. 'Promoting and protecting mental health as flourishing', American Psychologist, 62: 95-108.

Keyes, C.L.M. 2009. 'Brief description of the Mental Health Continuum Short Form (MHC-SF).' [online] URL: http//www.sociology.emory.edu/ckeyes/. Accessed 14 December 2010.

Keyes, C.L.M. \& Annas, J. 2009. 'Feeling good and functioning well: Distinctive concepts in ancient philosophy and contemporary science', Journal of Positive Psychology, 4: 197-201.

Keyes, C.L.M. \& Haidt, J. 2003. Flourishing: Positive psychology and the life well-lived. Washington, DC: American Psychological Association.

Keyes, C.L.M., Wissing, M., Potgieter, J.P., Temane, M., Kruger, A. \& Van Rooy, S. 2008. 'Evaluation of the Mental Health Continuum Short Form (MHC-SF) in Setswana speaking South Africans', Clinical Psychology and Psychotherapy, 15: 181-192.

Kline, R.B. 2010. Principles and practice of structural equation modelling ( $3^{\text {rd }}$ Edition.). New York: Guilford Press.

Lambert, S.J. 2006. 'Both art and science: Employing organizational documentation in workplace-based research'. In Pitt-Catsouphes, M. Kossek, E.E. \& Sweet, S. (Eds.). The work and family handbook: Multi-disciplinary perspectives, methods, and approaches. Mahwah, NJ: Lawrence Erlbaum Associates, p.p. 503-525.
Lambert, E.G., Hogan, N.L. \& Barton, S.M. 2001. 'The impact of job satisfaction on turnover intent: A test of a structural measurement model using a national sample of workers', The Social Science Journal, 38: 233-250.

LePine, J.A., Erez, A. \& Johnson, D.E. 2002. 'The nature and dimensionality of organizational citizenship behaviour: A critical review and meta-analysis', Journal of Applied Psychology, 87: 52-65.

Lowry, G., Turner, R. \& Fisher, J. 2006. 'The contribution of employment satisfaction factors to recruiting, retaining and career development of information systems and technology professionals', The Review of Business Information Systems, 10: 137-150.

Lyubomirsky, S., King, L. \& Diener, E. 2005. 'The benefits of frequent positive affect: Does happiness lead to success?' Psychological Bulletin, 131: 803-855.

Lyubomirsky, S., Sheldon, K.M. \& Schkade, D. 2005. 'Pursuing happiness: The architecture of sustainable change', Review of General Psychology, 9: 111-131.

Meyer, J.P. \& Allen, N.J. 1997. Commitment in the workplace: Theory, research and application. Thousand Oaks, CA: SAGE Publications.

Moore, J.E. \& Burke, L.A. 2002. 'How to turn around 'turnover culture' in IT', Communications of the ACM, 45: 73-78.

Moore, J.E. \& Love, M.S. 2005. 'IT professionals as organizational citizens', Communications of the ACM, 48: 89-93.

Morgan, J. \& Farsides, T. 2008. 'Measuring meaning in life', Journal of Happiness Studies. [online]URL:http://www.springerlink.com/content/3x17252 45j2605n6/.

Nunnally, J.C. \& Bernstein, I.H. 1994. Psychometric theory ( $3^{\text {rd }}$ Edition). New York: McGraw-Hill.

Organ, D.W. 1988. Organizational citizenship behavior: The good soldier syndrome. Lexington, MA: Lexington Books.

Organ, D.W. 1990. 'The motivational basis of organizational citizenship behaviour.' In Staw, B.M. \& Cummings, L.L. (Eds.). Research in organizational behaviour. Greenwich, CT: JAI Press, p.p. 43-72.

Ouwencel, E., LeBlanc, P.M. \& Schaufeli, W.B. 2011. 'Flourishing students: A longitudinal study on positive emotions, personal resources, and study engagement', The Journal of Positive Psychology, 6: 142-153.

Pierce, J.L. \& Gardner, D.G. 2004. 'Self-esteem within the work and organizational context: A review of the 
organizational-based self-esteem literature', Journal of Management, 30: 591-622.

Porter, L.W., Steers, R.M., Mowday, R.T. \& Boulian, P. 1974. 'Organizational commitment, job satisfaction, and turnover among psychiatric technicians', Journal of Applied Psychology, 59: 603-609.

Preacher, K.J. \& Hayes, A.F. 2008. 'Asymptotic and resampling strategies for assessing and comparing indirect effects in multiple mediator models', Behavior Research Methods, 40: 879-891.

Preacher, K.J. \& Hayes, A.F. 2009. 'Beyond Baron and Kenny: Statistical mediational analysis in the new millennium', Communication Monographs, 76: 408-420.

Price, J. 1997. 'Handbook of organisational measurement', International Journal of Manpower, 18: 303-558.

Price, J.L. 2001. 'Reflections on the determinants of voluntary turnover', International Journal of Manpower, 22: 660-624.

Puffer, S.M. 1987. 'Prosocial behaviour, non-compliant behaviour, and work performance among commission salespeople', Journal of Applied Psychology, 72: 615-621.

Rhoades, L., Eisenberger, R. \& Armeli, S. 2001. 'Affective commitment to the organization: The contribution of perceived organizational support', Journal of Applied Psychology, 86: 825-836.

Robbins, S.P., Judge, T.A., Odendaal, A. \& Roodt, G. 2009. Organisational behaviour: Global and Southern African perspectives. Cape Town: Pearson Education.

Roodt, J. \& Paterson, A. 2008. 'ICT skills in the labour market: An occupational-level analysis focusing on computer professionals and associate professionals, 19962005: Scarce and critical skills research project for the Department of Labour in South Africa.' [online] URL:http://www.labour.gov.za/downloads/documents/resea rcdocuments/ICT\%20skills_DoL_Report.pdf.

Rothmann, S. 2010. The reliability and validity of measuring instruments of happiness in the Southern African context. Vanderbijlpark: North-West University.

Rousseau, D.M. 1998. 'Why workers still identify with organizations', Journal of Organizational Behavior, 19: 217-233.

Ryff, C.D. 1989. 'Happiness is everything, or is it? Explorations on the meaning of psychological well-being', Journal of Personality and Social Psychology, 57: 10691081.

Schnake, M., Cochran, D. \& Dumler, M. 1995. 'Encouraging organizational citizenship: The effects on job satisfaction, perceived equity and leadership', Journal of Managerial Issues, 7: 209-221.

Seligman, M.E.P. \& Csikszentmihalyi, M. 2000. 'Positive psychology: An introduction', American Psychologist, 55: 5-14.

Sjöberg, A. \& Sverke, M. 2000. 'The interactive effect of job involvement and organizational commitment revisited: A note on the mediating role of turnover intention', Scandinavian Journal of Psychology, 41: 247-252.

Smith, C.A., Organ, D.W. \& Near, J.P. 1983. 'Organizational citizenship behavior: Its nature and antecedents', Journal of Applied Psychology, 68: 653-663.

Sparks, K., Faragher, B. \& Cooper, C.L. 2001. 'Well-being and occupational health in the 21st century workplace', Journal of Occupational and Organizational Psychology, 74: 489-509.

Spector, P. E. \& Fox, S. 2005. 'The stressor-emotion model of counterproductive work behavior.' In Fox, S. \& Spector, P.E. (Eds.). Counterproductive work behavior: Investigations of actors and targets. Washington, DC: American Psychological Association, p.p. 151-174.

Spector, P., Fox, S., Penney, L.M., Bruursema, K., Goh, A. \& Kessler, S. 2006. 'The dimensionality of counterproductivity: Are counterproductive behaviours created equal?' Journal of Vocational Behavior, 68: 446-460.

SPSS Inc. 2011. SPSS 19.0 for Windows. Chicago, IL: SPSS Inc.

Sverke, M., Hellgren, J. \& Näswall, K. 2002. 'No security: A meta-analysis and review of job security and its consequences', Journal of Occupational Health Psychology, 7: 242-264.

Thatcher, J.B., Stepina, L.P. \& Boyle, R.J. 2002. 'Turnover of IT workers: Examining empirically the influence of attitudes, job characteristics and external markets', Journal of Management Information Systems, 19: 231-261.

Thoresen, C.J., Kaplan, S.A., Barsky, A.P., Warren, C.R. \& de Chermont, K. 2003. 'The affective underpinnings of job perceptions and attitudes: A meta-analytic review and integration', Psychological Bulletin, 129: 914-945.

Torrington, D., Hall, L. \& Taylor, S. 2008. Human resource management ( $7^{\text {th }}$ Edition). Harlow, FT: Pearson Education.

Trimble, D.E. 2006. 'Organizational commitment, job satisfaction, and turnover intention of missionaries', Journal of Psychology and Theology, 34: 349-360.

Tugade, M.M. \& Fredrickson, B.L. 2004. 'Resilient individuals use positive emotions to bounce back from negative emotional experiences', Journal of Personality and Social Psychology, 86: 320-333. 
Turner, R. \& Lowry, G. 2000. 'Motivating and recruiting intending IS professionals: A study of what attracts IS students to prospective employment', South African Computer Journal, 24: 132-137.

Van Dyne, L., Graham, J.W. \& Dienesch, R.M. 1994. 'Organizational citizenship behavior: Construct, definition, measurement, and validation', Academy of Management Journal, 37: 765-802.

Vella-Brodrick, D., Park, N. \& Peterson, C. 2009. 'Three ways to be happy: Pleasure, engagement, and meaning: Findings from Australian and US samples', Social Indicators Research, 90: 156-179.

Woon, I. M. Y. \& Pee, L. G. 2004. Behavioral factors affecting internet abuse in the workplace: An empirical investigation. Proceedings of the Third Annual Workshop on HCI Research in MIS, Washington.

Yilmaz, K. \& Cokluk-Bokeoglu, O. 2008. 'Organizational citizenship behaviors and organizational commitment in Turkish primary schools', World Applied Sciences Journal, 3: 775-780.

Youssef, C.M. \& Luthans, F. 2012. 'Positive global leadership’, Journal of World Business, 47: 539-547. 